\title{
Cation Fluxes Cause Plasma Membrane Depolarization Involved in $\beta$-Glucan Elicitor-Signaling in Soybean Roots
}

\author{
Axel Mithöfer, ${ }^{1}$ Jürgen Ebel, ${ }^{2}$ and Hubert H. Felle ${ }^{3}$ \\ ${ }^{1}$ Max-Planck-Institut für Chemische Ökologie, Bioorganische Chemie, Hans-Knöll-Str. 8, D-07745 Jena, Germany; \\ ${ }^{2}$ Department Biologie I der Ludwig-Maximilians-Universität, Botanik, Menzinger Str. 67, D-80638 München, Germany; \\ ${ }^{3}$ Botanisches Institut I, Universität Gießen, Senckenbergstraße 17, D-35390 Gießen, Germany \\ Submitted 25 February 2005. Accepted 9 May 2005.
}

\begin{abstract}
Inducible and specific ion fluxes on plasma membranes represent very early events during elicitation of plant cells. The hierarchy of such ion fluxes involved is still unknown. The effect of Phytophthora sojae-derived $\beta$-glucan elicitors on the plasma membrane potential as well as on surface $\mathrm{K}^{+}, \mathrm{Ca}^{2+}$, and $\mathrm{H}^{+}$fluxes has been investigated on soybean roots using ion-selective microelectrodes. $\beta$-Glucans with different degrees of polymerization transiently depolarized the plasma membrane. The elicitor concentration necessary for half-maximal depolarization closely resembled the corresponding binding affinities of soybean root membranes toward the respective $\beta$-glucans. Upon repeated elicitor treatment, the root cells responded partially refractory, suggesting a complex responsiveness of the system. Within the root hair space, characteristic decreasing $\mathrm{K}^{+}$- and $\mathrm{Ca}^{2+}$ free concentrations were induced by the elicitors, probably causing depolarization through the influx of positive charges. Whereas $\mathrm{K}^{+}$fluxes were inverted after passing the $\mathrm{K}^{+}$equilibrium (Nernst-) potential, $\mathrm{Ca}^{2+}$ influx continued. No anion fluxes sufficient to account for charge compensation were observed under the same experimental conditions. $\mathrm{K}^{+}$and $\mathrm{Ca}^{2+}$ fluxes as well as depolarization were inhibited by $100 \mu \mathrm{M}$ or less of the $\mathrm{Ca}^{2+}$ antagonist $\mathrm{La}^{3+}$. Contrasting other systems, in soybean the main cause for elicitor-induced plasma membrane depolarization is the activation of cation instead of anion fluxes.
\end{abstract}

Additional keywords: $\beta$-Glucan receptor, Glycine max.

Plant roots take up water and a variety of nutrients from the soil. Thus, they are exposed to soilborne attacking or symbiotic microorganisms, whereby roots and root hairs function as highly sensitive microantennas for compounds released from such microorganisms. Root cells have developed a highly efficient and specific chemosensorial machinery to recognize chemical signals at very low concentrations (Boller 1995). If derived from pathogenic microorganisms, these signals (elicitors; e.g., oligosaccharides, glycoproteins, peptides, and fatty acids) induce specific signaling processes that activate defense reactions in the host plants (Boller 1995; Ebel and Scheel 1997; Nürnberger and Scheel 2001; Shibuya and Minami 2001). Moreover, a variety of "active" substances (e.g., cell-wall-degrading enzymes such as cellu-

Corresponding author: A. Mithöfer; Telephone: ++49 3641 571263; Fax: ++49 3641 571256; E-mail: amithoefer@ice.mpg.de lases, xylanases, or pectinases) reaches the plant surface and elicits responses as well.

Soybean (Glycine max L.) is known to respond to elicitation with $\beta$-glucans-derived from cell walls of the phytopathogenic oomycete Phytophthora sojae and carrying the hepta$(1,3-1,6)$ - $\beta$-glucoside motif-in a manner comparable with soybean plants challenged with the pathogen (Ebel 1998). The $(1,3-1,6)-\beta$-glucan elicitors are very well characterized with regard to their biological activities in differentiated plants and cell cultures, and to the biochemical properties of the receptor-ligand interactions (Ebel 1998; Ebel and Mithöfer 1998). Recently, the cloned hepta- $\beta$-glucoside-binding protein cDNAs from soybean and French bean (Phaseolus vulgaris L.) have been identified as members of a putative receptor family in legumes (Mithöfer et al. 2000). Upon $\beta$-glucan binding to the receptor, various early signaling events are initiated within minutes, such as a transient increase of the free cytosolic $\mathrm{Ca}^{2+}$ concentration and the activation of protein kinases. Moreover, the synthesis of reactive oxygen species and, after a couple of hours, specific gene activations have been observed (Ebel and Mithöfer 1998). In soybean and other legumes, distinct cellular reactions finally lead to the accumulation of phytoalexins, representing one important part of a set of inducible defense reactions (Cosio et al. 1996; Ebel 1998).

Other typical early plant responses to elicitor signals are voltage changes at the plasma membrane, usually a depolarization (Felle et al. 2000; Kikuyama et al. 1997; Mathieu et al. 1991; Pugin et al. 1997; Thain et al. 1995), and different ion fluxes (Felle et al. 2000; Jabs et al. 1997; Kadota et al. 2004; Kuchitsu et al. 1997; Mathieu et al. 1991; Pugin et al. 1997; Wendehenne et al. 2002), of which the external alkalinization may be the best known (Boller 1995). The meaning and function of these early events on the plasma membrane is still a matter of debate. The ion fluxes could be part of either the receptor-mediated signal transduction cascade or the plant defense reactions. However, a voltage change at the plant plasma membrane cannot represent a signal involved in the crosstalk of microorganisms and plants because it does not reach the causative microbe. On the other hand, external changes of ion activities might be, and probably are, signals directed to the attacking organisms. External alkalinization, for example, could make transport capacities unfavorable with respect to the proton-motive force required for an effective transport of organic substrates. This, however, only holds true in cases of persistent alkalinization, which is not always the case (Felix et al. 1993). Likewise, the hierarchy of ion fluxes that occur in response to an elicitor is still quite uncertain, although a general consensus 
seems to emerge that, upon the perception of an elicitor by the corresponding receptor, at first a $\mathrm{Ca}^{2+}$ channel might be activated. As a consequence, cytosolic $\mathrm{Ca}^{2+}$ activity increases that activates anion channels and, in turn, the anion efflux causes plasma membrane depolarization. This sequence has been suggested for elicitors such as the oligopeptide elicitor in parsley (Nürnberger et al. 1994), cryptogein and oligogalacturonides in tobacco (Kadota et al. 2004; Lecourieux et al. 2002; Wendehenne et al. 2002), and chitooligosaccharides in rice (Kuchitsu et al. 1997) and alfalfa (Felle et al. 2000), as well as for symbiotic Nod factors in alfalfa (Felle et al. 1998, 2000). Nevertheless, other scenarios resulting in the induction of depolarization are feasible, as are deactivation of the plasma membrane $\mathrm{H}^{+}$-ATPase, activation of a $\mathrm{K}^{+}$channel, or an unspecific increase of membrane conductance.

In the present study using soybean root cells challenged by $\beta$-glucan elicitors, we show that the activation of cation fluxes involving $\mathrm{K}^{+}$and $\mathrm{Ca}^{2+}$ is the predominant event leading to membrane depolarization instead of anion fluxes. To demonstrate this, we analyzed and characterized the effects of $\beta$-glucan elicitors on both the plant plasma membrane potential and, using ion-selective microelectrodes, on ion fluxes within the root hair space before and during elicitor action.

\section{RESULTS}

\section{The basic depolarization response.}

Soybean root cortex cells as well as root hair cells were used to analyze the change of their plasma membrane potential in response to treatment with Phytophthora sojae-derived $\beta$-glucan elicitors. The addition of $\beta$-glucans with a degree of polymerization of (DP) 7 to 15 (DP7-15) induced a concentrationdependent membrane depolarization (Fig. 1). A slight reaction was already detectable at approximately $10 \mathrm{nM}$ DP7-15 elicitor (data not shown). Depolarization was saturated at approximately $10 \mu \mathrm{M}$ and the effector concentration necessary for the induction of the half-maximal response $\left(\mathrm{EC}_{50}\right)$ was calculated to be approximately $280 \mathrm{nM}$ (Fig. 1B; Table 1). The onset of the membrane potential change upon elicitor treatment was delayed, which was proven by the addition of $20 \mathrm{mM} \mathrm{KCl}$ which, upon encounter with the plasma membrane, caused an immediate depolarization without any delay (Fig. 1A). At halfmaximal elicitor concentration, this lag-phase persisted for 1 to $2 \mathrm{~min}$. At lower elicitor concentrations, the response delay increased (data not shown).
Specificity of plasma membrane depolarization.

In order to investigate the specificity of the depolarization response, a variety of $\beta$-glucan fractions were used as elicitors. All $\beta$-glucans with a DP greater than 5 were highly efficient stimulants of depolarization (Fig. 2). Depending on the DP of the $\beta$-glucans tested, this membrane response differed to some extent; as such, DP15 elicited stronger responses than equal concentrations of DP7-15 or DP16-24, the latter two being about equally active. No depolarization was observed in the presence of DP5 at any concentration tested between 0.1 and 5 $\mu \mathrm{M}$. A comparison of these biological activities of the various $\beta$-glucans with the corresponding binding activities to the $\beta$ glucan receptor in soybean roots is presented in Table 1 . The data suggest a direct correlation between the apparent binding affinity for a certain $\beta$-glucan fraction (expressed as $\mathrm{IC}_{50}$, the required concentration for half-maximal displacement of the hepta- $\beta$-glucoside radioligand) (Cosio et al. 1990; Mithöfer et al. 2000) and the corresponding apparent depolarization activity (shown as $\mathrm{EC}_{50}$, which was calculated from Fig. $2 \mathrm{~B}$ by nonlinear regression analysis using logistic curve fitting).

\section{Desensitization of the depolarization response.}

Various specific perception systems for signaling molecules in plants have been described to show a desensitization effect when treated with the same elicitor for a second time (Felix et al. 1993, 1998; Felle et al. 1995; Granado et al. 1995). A second and third addition of DP15, following an initial treatment with the identical $\beta$-glucan elicitor and subsequently a washout and recovery phase, caused a depolarization response that became progressively weaker, although the response was not abolished altogether during the period investigated (Fig. 3A).

Table 1. Correlation between the apparent soybean root cell depolarization activity $\left(\mathrm{EC}_{50}\right)$ for $\beta$-glucan fractions with various degrees of polymerization (DP) and the corresponding apparent binding affinity $\left(\mathrm{IC}_{50}\right)$ of soybean root membranes ${ }^{\mathrm{a}}$

\begin{tabular}{lcc}
\hline $\boldsymbol{\beta}$-Glucans & $\mathbf{E C}_{\mathbf{5 0}}(\mathbf{n M})$ & $\mathbf{I C}_{\mathbf{5 0}}(\mathbf{n M})$ \\
\hline DP5 & ND & $>6,000$ \\
DP7-15 & 280 & 250 \\
DP15 & 120 & 180 \\
DP16-24 & 190 & 40 \\
\hline
\end{tabular}

${ }^{a}$ Effector concentration necessary for the induction of the half-maximal response $\left(\mathrm{EC}_{50}\right)$ values were calculated by nonlinear regression analysis using logistic curve fitting. ND = not determined.
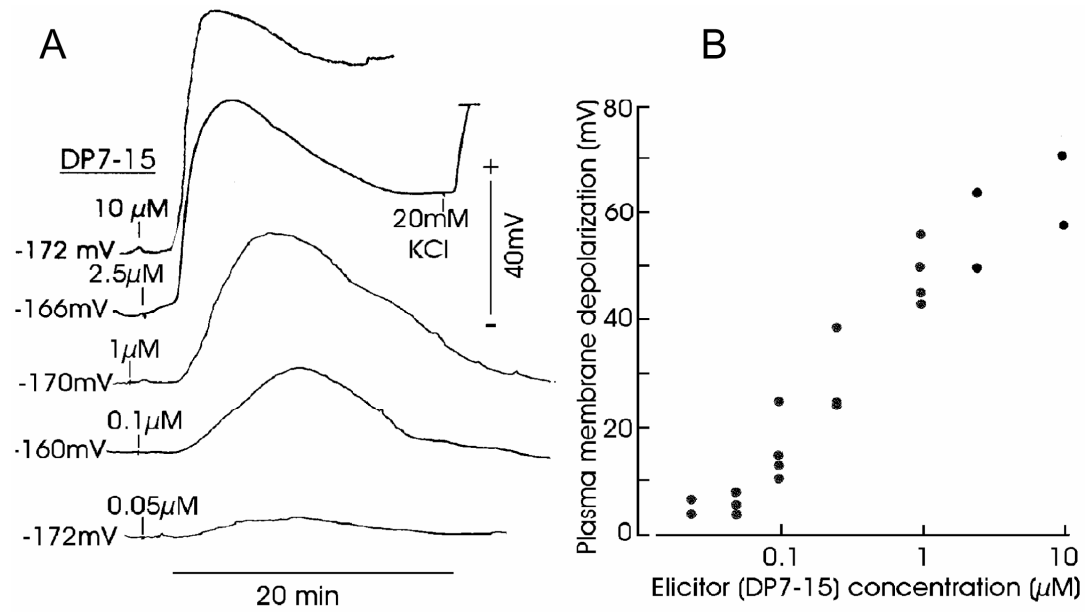

Fig. 1. Dose-response relationship of $\beta$-glucan elicitor (DP7-15) on the plasma membrane potential of soybean root cells. A, Kinetics of depolarization. At the end of each test, $20 \mathrm{mM} \mathrm{KCl}$ was added (only shown with $2.5 \mu \mathrm{M} \mathrm{DP7-15}$ ) to determine the lag-phase. B, Maximal depolarization measured at the indicated DP7-15 concentrations. Each data point represents an independent determination. 
Likewise, when DP7-15 was added following DP15 treatment, the response also was reduced by approximately 50\% (Fig. 3B). No such effect was observed when the effective DP16-24 elicitor was tested after the addition of the apparently inactive DP5 fraction (Fig. 3C).

\section{$\beta$-Glucan-induced ion fluxes in soybean root cells.}

Ion-selective microelectrodes are valuable tools for studying ion fluxes across membranes (Felle 1993; Newman 2001). The induction of such ion fluxes represent an integral part of early plant responses to elicitors (Felix et al. 1993; Kadota et al. 2004; Kuchitsu et al. 1997; Lecourieux et al. 2002; Mathieu et al. 1991; Mithöfer et al. 1999; Nürnberger et al. 1994; Wendehenne et al. 2002) or Nod factors (Felle et al. 1998; Kurkdjian et al. 2000). Although, in the former studies, fluxes of $\mathrm{Ca}^{2+}, \mathrm{Cl}^{-}$, or $\mathrm{NO}_{3}^{-}, \mathrm{H}^{+}$, and $\mathrm{K}^{+}$are described to take place upon encounter with the respective first signaling molecules, their temporal sequence and physiological poise has not yet been cleared up
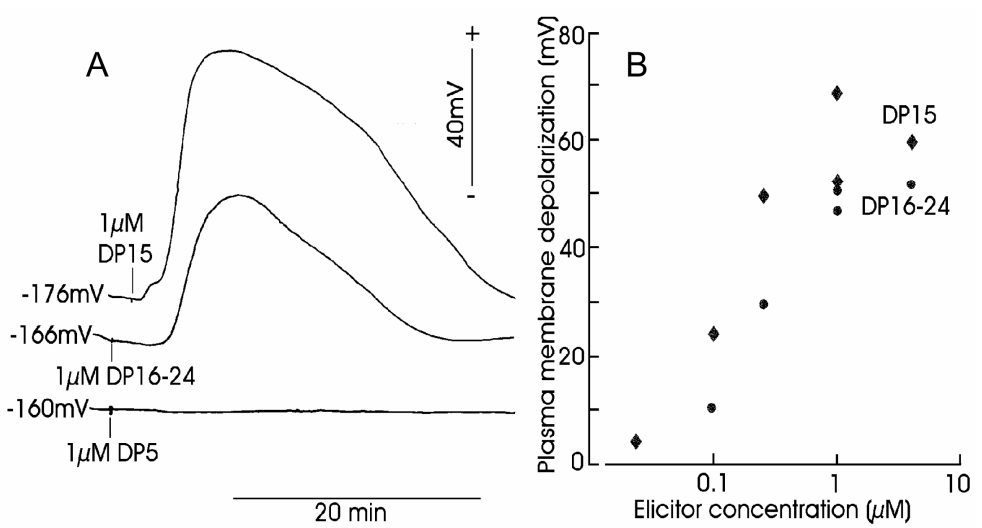

Fig. 2. Specificity of $\beta$-glucan elicitors differing in the degree of polymerization (DP5, DP15, and DP16-24) on the plasma membrane potential of soybean root cells. A, Kinetics of elicitor-induced changes in plasma membrane potential. B, Concentration-dependent maximal depolarization induced by DP15 and DP16-24.
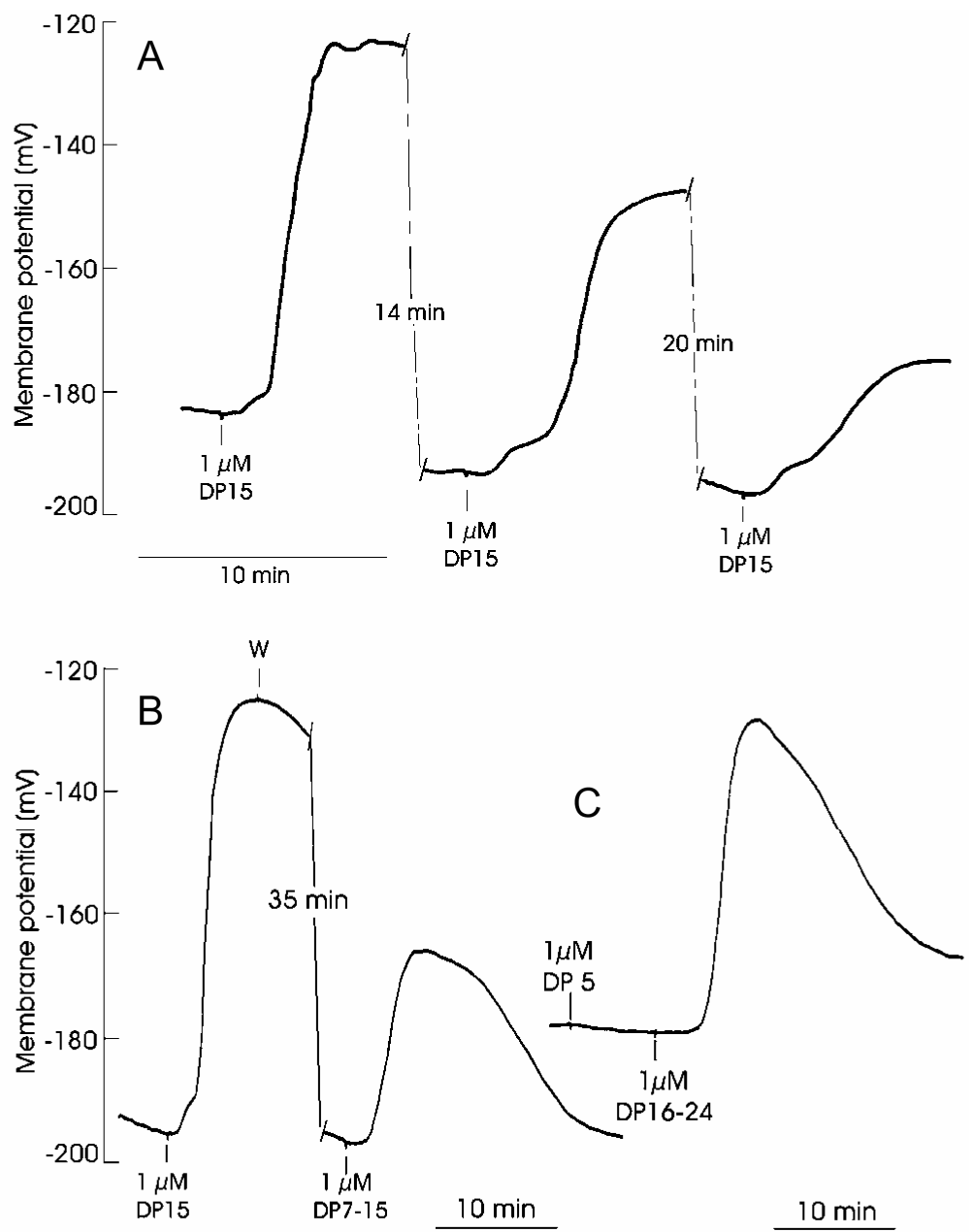

Fig. 3. Desensitization and mutual interference of $\beta$-glucan elicitors with different degrees of polymerization. A, Plasma membrane potential of soybean root cells after repeated addition of DP15 at $1 \mu \mathrm{M}$. Time of washout procedure between the treatments as indicated. Effect of DP7-15 on membrane potential following a foregoing treatment with B, DP15 or C, DP5 and DP16-24. 
in all cases. In order to analyze the hierarchy of the $\beta$-glucaninduced ion fluxes in soybean root cells, we used ion-specific microelectrodes. The extracellular root hair space suffered a loss of $\mathrm{Ca}^{2+}$ after the addition of $1 \mu \mathrm{M}$ DP7-15 or DP15 (Fig. 4). Simultaneously, measured on the same root, the external $\mathrm{K}^{+}$ activity dropped within the first $2 \mathrm{~min}$ but recovered partially or completely. Also, the membrane depolarization has been recorded simultaneously with the changes in external $\mathrm{K}^{+}$and $\mathrm{Ca}^{2+}$ activities. Given a cytosolic root hair $\mathrm{K}^{+}$concentration of 70 to $90 \mathrm{mM}$ (as determined by measuring the diffusion potential at different external $\mathrm{K}^{+}$concentrations) and measuring 50 to $60 \mu \mathrm{M} \mathrm{K}^{+}$in the root hair space, an equilibrium potential for $\mathrm{K}^{+}\left(\mathrm{E}_{\mathrm{K}}\right)$ can be calculated (Fig. 4A, shaded bar). Moreover, external $\mathrm{K}^{+}$concentration decreased as long as the membrane voltage was negative to $E_{K}$, but recovered (increased) to again reach the initial concentration after getting positive to $E_{K}$. The $\mathrm{Ca}^{2+}$ equilibrium potential is far more positive; therefore, the $\mathrm{Ca}^{2+}$ fluxes were not affected that way (Fig. 4A).

Using the same technique, no or only minor anion movements within the root hair space were detected during these events, a finding which differed considerably from the massive transient $\mathrm{Cl}^{-}$fluxes measured in alfalfa (Felle et al. 1998, 2000). This also counts for $\mathrm{NO}_{3}^{-}$because the $\mathrm{Cl}^{-}$electrode used in the present study senses $\mathrm{NO}_{3}^{-}$as well. Consequently, no effect of the anion channel inhibitors anthracene-9-carboxylate (A9C) and 5-nitro-2-(3-phenylpropylamino)-benzoate (NPPB) was detectable on the $\beta$-glucan elicitor-induced depolarization (data not shown). On the other hand, $\mathrm{La}^{3+}$ (a well known inhibitor of $\mathrm{Ca}^{2+}$ and $\mathrm{K}^{+}$channels) strongly inhibited $\beta$-glucan-induced $\mathrm{K}^{+}$and $\mathrm{Ca}^{2+}$ fluxes (Fig. 5A and $\mathrm{B}$ ) as well as the accompanying depolarization in a concentrationdependent manner (Fig. 6). Nifedipine, an inhibitor of voltagegated $\mathrm{Ca}^{2+}$ channels, had no effect on either depolarization or on $\mathrm{Ca}^{2+}$ or $\mathrm{K}^{+}$fluxes (data not shown).

External alkalinization, a typical elicitor response in plant cells (Felix et al. 1993; Felle et al. 2000; Kadota et al. 2004; Kuchitsu et al. 1997), also could be demonstrated after addition of the $\beta$-glucan elicitor, albeit the response to $1 \mu \mathrm{M}$ elicitor was less than half a $\mathrm{pH}$ unit (Fig. 5C, inset). The addition of $100 \mu \mathrm{M} \mathrm{La}^{3+}$, which itself strongly acidified the root hair space, eliminated the elicitor-induced $\mathrm{pH}$ increase (Fig. 5C).
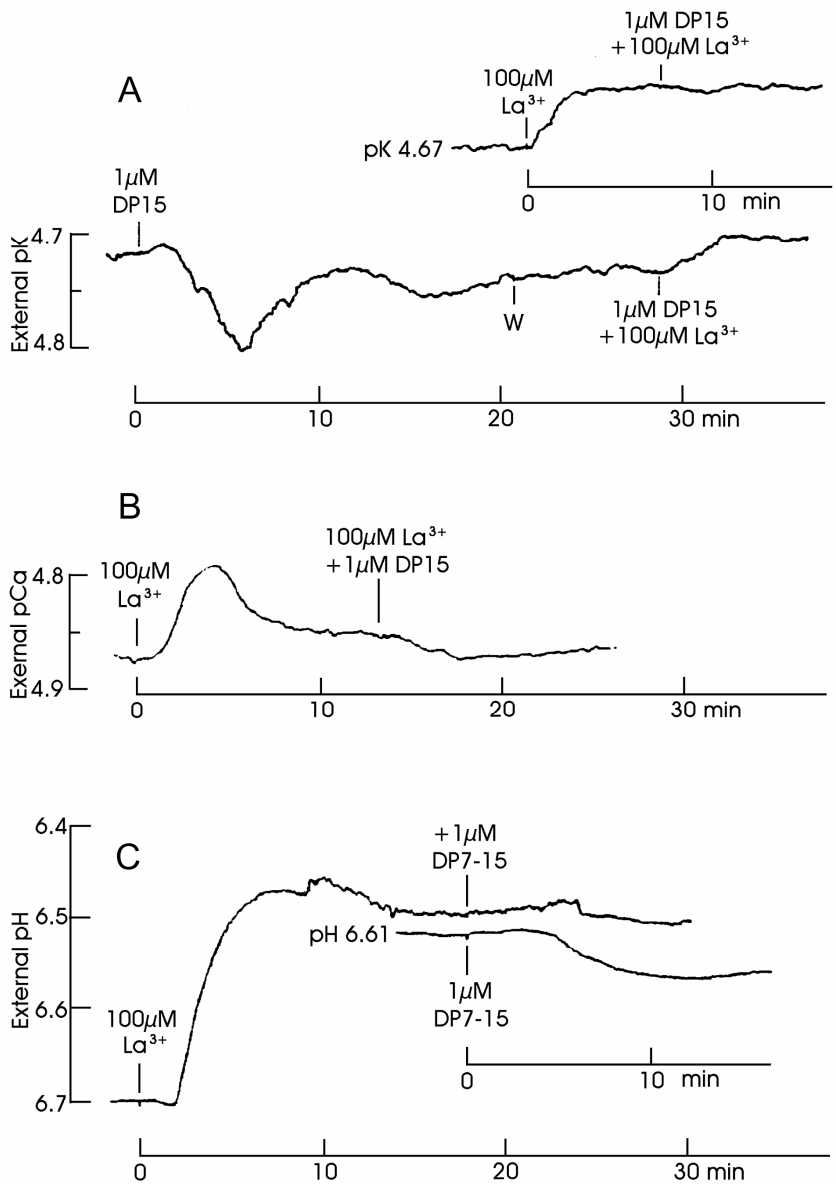

Fig. 5. Effect of $\mathrm{La}^{3+}\left(\mathrm{LaCl}_{3}\right)$ on $\beta$-glucan-induced ion fluxes, measured within the root hair space of soybean. A, Elicitor-induced changes in $\mathrm{K}^{+}$ activity (pK) followed by joint addition of $1 \mu \mathrm{M}$ DP15 and $100 \mu \mathrm{M} \mathrm{La}^{3+}$; $\mathrm{W}=$ removal of elicitor. Inset: Addition of $\mathrm{La}^{3+}$ followed by joint addition of $\mathrm{La}^{3+}+$ DP15. B, Changes in external $\mathrm{Ca}^{2+}$ activity (pCa) after addition of $\mathrm{La}^{3+}$ followed by joint addition of $\mathrm{La}^{3+}+\mathrm{DP} 15 . \mathbf{C}$, Changes in external $\mathrm{pH}$ after addition of $\mathrm{La}^{3+}$ followed by joint addition of $\mathrm{La}^{3+}+\mathrm{DP} 7-15$.
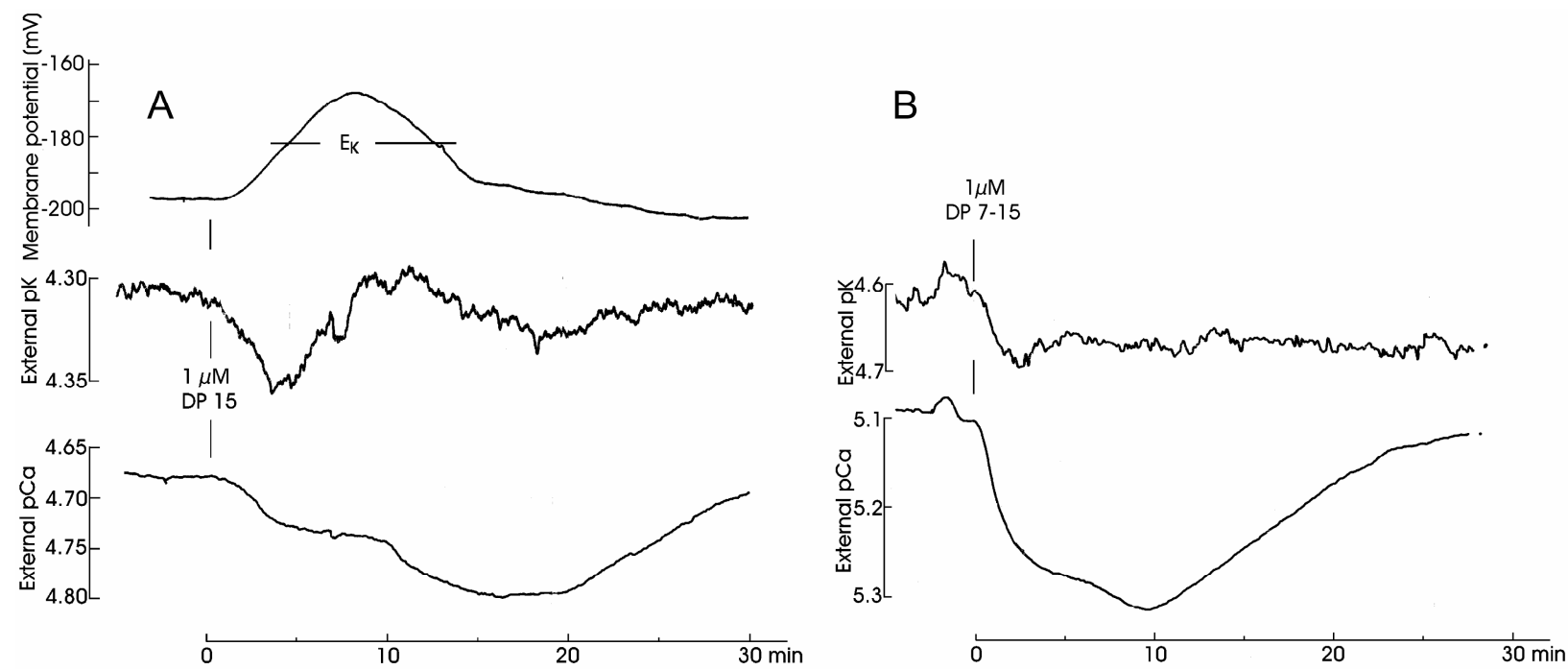

Fig. 4. $\mathrm{K}^{+}$and $\mathrm{Ca}^{2+}$ fluxes within the root hair space of soybean following addition of $\beta$-glucan elicitors with different degrees of polymerization. A, Effect of $1 \mu \mathrm{M}$ DP15. Simultaneous measurement of membrane potential, $\mathrm{Ca}^{2+}$ activity $(\mathrm{pCa})$, and $\mathrm{K}^{+}$activity $(\mathrm{pK})$. $\mathrm{E}_{\mathrm{K}}$ is the transmembrane equilibrium potential as determined from the cytosolic $\mathrm{K}^{+}$activity and measured external $\mathrm{K}^{+}$activity. Cytosolic $\mathrm{K}^{+}$activity of 70 to $90 \mathrm{mM}$ was determined by measuring the diffusion potential (e.g., in the presence of cyanide) at different external $\mathrm{K}^{+}$activities (data not shown). $\mathbf{B}, \mathrm{K}^{+}$and $\mathrm{Ca}^{2+}$ activities, measured after the addition of DP7-15. 


\section{DISCUSSION}

Using sensitive electrophysiological methods that permit online analysis, we demonstrated that different $\beta$-glucan elicitor fractions from the mycelium of $P$. sojae induced concentration-dependent and specific responses at the plasma membrane of soybean root cells. As typical for elicitors, the first measurable cell physiological response occurred with an apparent lagphase. This period probably is consumed by the perception of the signal molecules and the subsequent processes of transduction and transformation of the respective signal and its propagation to the corresponding cellular targets; a phenomenon typical for receptor-mediated signaling cascades and observed for several signaling processes.

In part, the $\beta$-glucan elicitor-induced depolarization is a refractory process (Fig. 3A). Although desensitization seems to be a common phenomenon for elicitor action, it is differently expressed in different test systems and it also depends on the type of elicitor used. Felix and associates (1993) demonstrated that, in tomato cell suspension cultures, the alkalinizationinducing ability of elicitors dropped to the detection limit, lasting $2 \mathrm{~h}$ in the case of xylanase and $4 \mathrm{~h}$ with chitotetraose. Our data revealed that, in soybean roots, the $\beta$-glucan response de- creased by $60 \%$ after approximately $1 \mathrm{~h}$, but did not reach zero even after repeated addition of the stimulus (Fig. 3A and data not shown). The partially refractory state of the $\beta$-glucan-treated root cells might suggest some so far unknown complexity of signal transduction in this system, possibly consisting of a refractory response of the true receptor and an additional responsiveness mediated by another nonrefractory binding site. A spontaneous recovery from depolarization events has been interpreted in terms of a desensitization of the specific perception system (Felix et al. 1998). In our study, such a monocausal interpretation collides with the ability of the system to respond a second time to the same signal. Thus, other mechanisms might be involved in the depolarization process of the membrane potential back to its resting level. It is conceivable that either activation through a nonrefractory elicitor-binding site of the plasma membrane $\mathrm{H}^{+}$-ATPase or, more likely, a spontaneous inactivation of elicitor-activated ion channels occurs, as indicated by the results of the $\mathrm{K}^{+}$measurements (Fig. 4).

Although elicitor-induced depolarization may be regarded as a common and not necessarily specific defense response, it has been proven to be a valuable tool in the investigation of membrane transport and functional perception of signal molecules (Felle et al. 2000; Kuchitsu et al. 1997; Mathieu et al. 1991;

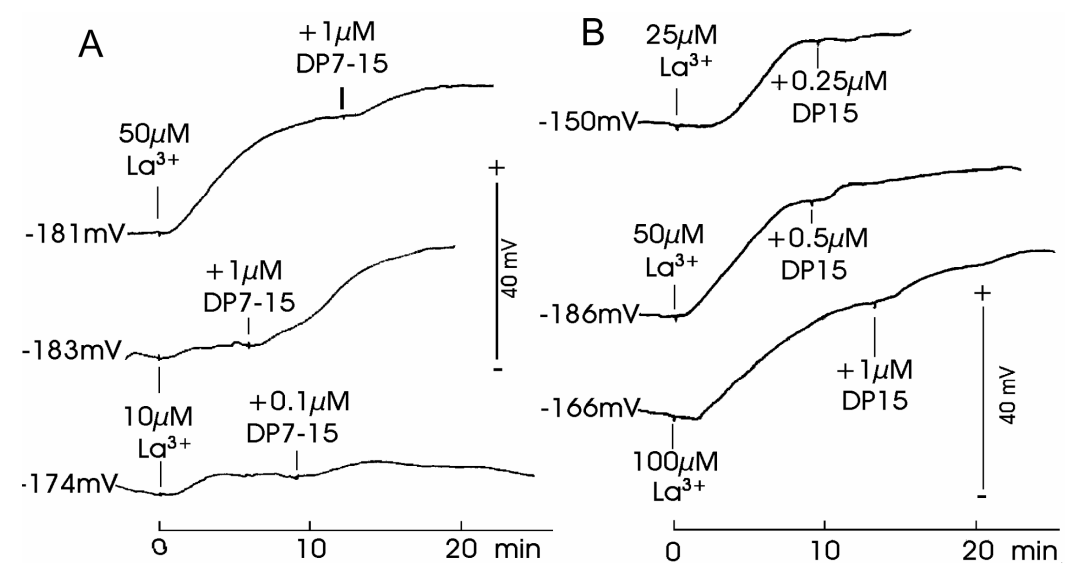

Fig. 6. Effect of $\mathrm{La}^{3+}$ on the plasma membrane potential of soybean root cells elicited by $\beta$-glucans. Depolarization induced by various concentrations of $\mathbf{A}$, DP7-15 or B, DP15 measured in the presence of the respective $\mathrm{La}^{3+}$ concentrations.

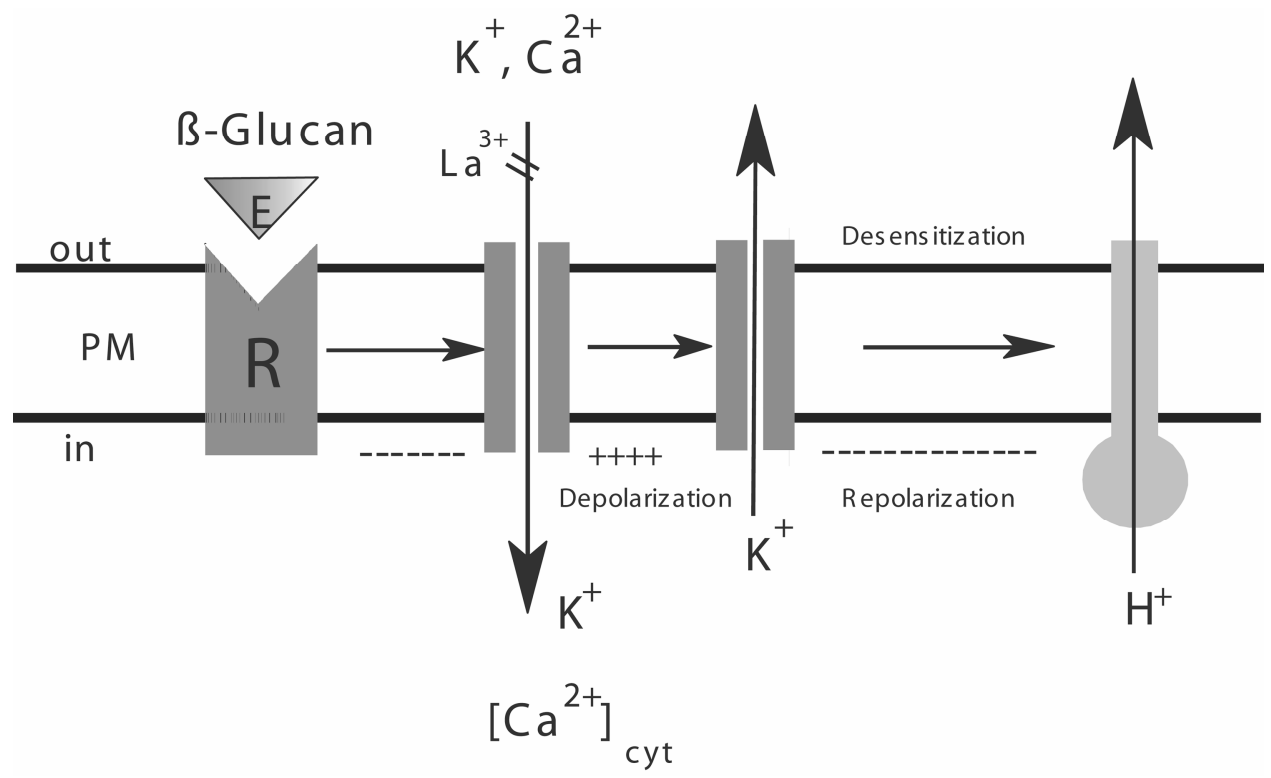

Fig. 7. Simplified model of the transmembrane ion fluxes involved in the $\beta$-glucan-induced depolarization of soybean root cells. PL $=$ plasma membrane and $\mathrm{E}=$ elicitor. 
Pelessier et al. 1986; Pike et al. 1998; Thain et al. 1995; Zimmermann et al. 1998). It should be stressed that depolarization of the host plasma membrane cannot be a signal to the attacking microorganism, but voltage changes may serve in channel gating within that membrane. Note that ion fluxes across the plasma membrane cause rapid changes of free ion concentrations within the root apoplast, at the surface of the root, or in the root hair space, because the respective fluid volumes are rather small. Thus, already a small amount of ions that move across the membrane might rapidly change the conditions for the attacking organism.

Following elicitor treatment, calcium influx might be the earliest measurable response, subsequently increasing cytosolic free $\mathrm{Ca}^{2+}$ (Blume et al. 2000; Felle et al. 2000; Lecourieux et al. 2002). For soybean, this has been demonstrated using the aequorin technique (Mithöfer et al. 1999, 2001). Although, thus far, $\mathrm{Ca}^{2+}$ ion influx has been considered as being too small to depolarize the plasma membrane, there are reports on large elicitor-induced $\mathrm{Ca}^{2+}$ influxes that are discussed to contribute to the depolarizing event (Kadota et al. 2004; Pugin et al. 1997; Zimmermann et al. 1997). Thus, our data are in full agreement with the idea that $\mathrm{Ca}^{2+}$ ions can carry a substantial portion of the depolarizing current (Fig. 4). Apart from $\mathrm{Ca}^{2+}$ fluxes, a delayed $\mathrm{K}^{+}$efflux has been observed that was regarded mainly as a charge-compensating and osmo-regulatory ion flux rather than related to a signaling cascade. Obviously, in soybean, this scenario is different. In root hair cells, after the usual lag-phase, $\beta$-glucan elicitors induced the onset of transient but substantial $\mathrm{Ca}^{2+}$ and $\mathrm{K}^{+}$influx, both following different kinetics. According to their flux direction at the beginning, both ions contributed to depolarization; however, as soon as the membrane potential had passed, the $\mathrm{E}_{\mathrm{K}}$, the driving force for $\mathrm{K}^{+}$, was inverted and $\mathrm{K}^{+}$left the cell thereafter (Fig. 4). By reducing the amount of depolarizing charges, this finally led to a voltage recovery, fuelled by the $\mathrm{H}^{+}$-ATPase. $\mathrm{Ca}^{2+}$ acts differently: despite the depolarization, an inwardly directed driving force remained active. Thus, the inversion of the $\mathrm{Ca}^{2+}$ flux did not mark a change in driving force, but more likely a spontaneous inactivation of the $\mathrm{Ca}^{2+}$ channel and, subsequently, the export of $\mathrm{Ca}^{2+}$, probably driven by the primary active $\mathrm{Ca}^{2+}$-ATPase. A comparison of the primary $\mathrm{K}^{+}$and $\mathrm{Ca}^{2+}$ losses from the root hair space until the onset of $\mathrm{K}^{+}$flux inversion yields $4.82 \mu$ moles $\mathrm{K}^{+}$and $2.05 \mu$ moles $\mathrm{Ca}^{2+}$ (DP15), and $4.26 \mu$ moles $\mathrm{K}^{+}$and $2.32 \mu$ moles $\mathrm{Ca}^{2+}$ (DP7-15), respectively, representing quite similar values. The numbers show that the poise of the initial depolarization current was on the side of $\mathrm{K}^{+}$, a situation that changed after the inversion of the $\mathrm{K}^{2+}$ current, because the depolarization process continued for some time (Fig. 4). The elicitor-induced and $\mathrm{La}^{3+}$ inhibited $\mathrm{Ca}^{2+}$ and $\mathrm{K}^{+}$fluxes as well as the accompanying depolarization (Fig. 6) is in line with observations of Zimmermann and associates (1997), who identified a $\mathrm{Ca}^{2+}$ - and $\mathrm{K}^{+}$-permeable, $\mathrm{La}^{3+}$-sensitive plasma membrane channel of high conductance in parsley protoplasts. This channel was reversibly activated upon treatment with an oligopeptide elicitor and has been considered to contribute to the elicitor-induced macroscopic ion fluxes in parsley.

Recently, Ivashikina and associates (2001) reported on a (GlcNAc) $)_{8}$ elicitor-induced activation of a $\mathrm{K}^{+}$channel (GORK) in Arabidopsis root hairs which finally led to membrane depolarization, presumably fuelled by anion efflux. However, whereas, in Arabidopsis, no primary $\mathrm{K}^{+}$influx was recorded and $\mathrm{K}^{+}$efflux started when the membrane potential had passed the $\mathrm{E}_{\mathrm{K}}$, in soybean, large $\mathrm{K}^{+}$influx preceded $\mathrm{K}^{+}$efflux.

The failure to detect anion efflux might have been caused by the elicitor sensitivity of the anion microelectrode, which could have masked the elicitor response. However, this idea is unlikely because of the absence of any inhibitory effect of NPPB or A9C on both the elicited depolarization and the poor $\mathrm{pH}$ response (Fig. 5C). This latter notion is based on the finding that efflux of organic anions that occurs simultaneously with the depolarizing $\mathrm{Cl}^{-}$efflux can be one of the reasons for external alkalinization (Felle et al. 1998, 2000). Thus, in the light of a seemingly weak anion channel involvement, the rather small $\beta$-glucan-elicited external alkalinization is evident. However, anion channel activation cannot be entirely excluded. We reported earlier that NPPB clearly inhibited the $\beta$-glucan-elicited increase of the cytosolic $\mathrm{Ca}^{2+}$ activity in soybean suspension-cultured cells treated with much greater elicitor concentrations $(100 \mu \mathrm{M})$ (Mithöfer et al. 2001). Because NPPB is not an inhibitor of $\mathrm{Ca}^{2+}$ channels but of anion channels, we concluded that, upon elicitor perception, first anion channels and subsequently $\mathrm{Ca}^{2+}$ channels were activated. However, a comparison with the data obtained in the present work using submicromolar elicitor concentrations might point to signaling systems with high versus low responsiveness for the $\beta$-glucan elicitor: high responsiveness in differentiated tissues such as roots or cotyledons (Cheong and Hahn 1991; Cosio et al. 1990; this work) and low responsiveness in undifferentiated suspension cells (Mithöfer et al. 1999). Although this phenomenon has been known for some time, the molecular mechanism behind it still is not clear. Thus, at an apparent sensitivity in the submicromolar range (Figs. 1 and 2; Table 1), the importance of anion channels for depolarization or the events leading to it must be rated as minor.

A sequence of causal relationships for $\beta$-glucan-elicited deand repolarization in soybean root cells is suggested: a cation $\left(\mathrm{Ca}^{2+}, \mathrm{K}^{+}\right)$influx causes depolarization which is followed by a repolarization mediated by a $\mathrm{K}^{+}$efflux (Fig. 7). This efflux is initiated after passing the $\mathrm{K}^{+}$equilibrium potential, while $\mathrm{Ca}^{2+}$ influx continues. Our proposal substantially differs to others in that no anion channel is included. To date, we have no definite information whether $\mathrm{K}^{+}$and $\mathrm{Ca}^{2+}$, in fact, move through the same channel, but the inhibition by submillimolar $\mathrm{La}^{3+}$ concentrations of both ion fluxes suggests this idea. Recently, for the plasma membranes of Arabidopsis as well as of wheat, root voltage-independent cation channels (VICs) have been described which are permeable to both $\mathrm{K}^{+}$and $\mathrm{Ca}^{2+}$ (Demidchik et al. 2002a; White and Davenport 2002). Inward currents through VICs are known to be sensitive to $\mathrm{La}^{3+}$ but insensitive to the $\mathrm{Ca}^{2+}$ channel inhibitor nifedipine (Demidchik et al. $2002 \mathrm{~b}$ ), consistent with the properties we found for the $\beta$-glucan-elicited depolarization in soybean (Figs. 5 and 6; data not shown). Moreover, the patch-clamp studies on parsley plasma membranes, showing an elicitor-responsive large conductance $\mathrm{Ca}^{2+}$ inward channel exhibiting $\mathrm{K}^{+}$inward conductance as well, supports our finding (Zimmermann et al. 1997). Thus, future work will focus on a detailed electrophysiological characterization of the $\beta$-glucan-activated cation channel in soybean root plasma membranes to elucidate its specific role in initiating defense mechanisms.

\section{MATERIALS AND METHODS}

\section{Plant material, $\beta$-glucan elicitors, and preparation of the roots.}

Soybean (Glycine max L. cv. 9007) seed were kindly provided by Pioneer, Buxtehude, Germany. Plants were grown for at least 10 days in a phytochamber as described elsewhere (Schmidt and Ebel 1987). $\beta$-Glucans with different DP were prepared from mycelia cell walls of the phytopathogenic oomycete $P$. sojae Kaufmann and Gerdemann and separated by gel chromatography to determine the apparent DP (Schmidt and Ebel 1987). In $\beta$-glucan mixtures, the average DP was used to calculate the $\beta$-glucan concentration on a molar basis (Cosio et al. 1990; Schmidt and Ebel 1987). 
Root pieces, approximately $2 \mathrm{~cm}$ long, were excised and fixed with candle wax on the bottom of a chamber which was constantly perfused with a solution usually containing $0.5 \mathrm{mM}$ Mes/Tris (pH 6.7 to 6.9), 0.01 to $1 \mathrm{mM} \mathrm{KCl}, 0.1 \mathrm{mM} \mathrm{NaCl}$, and 0.01 to $0.1 \mathrm{mM} \mathrm{CaCl}_{2}$; any conditions different from these are given in the figure captions or text. Desired $\beta$-glucan elicitor concentrations were obtained by diluting aqueous stock solutions of $100 \mathrm{mM}$ DP5, $25 \mathrm{mM}$ DP7-15, $0.3 \mathrm{mM}$ DP16-24, and $30 \mathrm{mM}$ DP15. Prior to all measurements, the seedlings were incubated in the basic test solution for at least $2 \mathrm{~h}$.

\section{Membrane potential measurements.}

The electrical set-up for the impalement of the root or root hairs and for recording of membrane potential has been described previously (Felle et al. 1995). The micropipettes were pulled from filamented borosilicate glass tubing (Hilgenberg, Malsfeld, Germany) to tips of approximately $0.5 \mu \mathrm{m}$, and were backfilled with $0.5 \mathrm{M} \mathrm{KCl}$. The $\mathrm{Ag} / \mathrm{AgCl}$ half-cells were connected with a high-impedance amplifier (S-7000; World Precision Instruments, Sarasota, FL, U.S.A.). Data were collected on a chart recorder (Linseis 22200, Selb, Germany). The response time to the elicitor (lag-phase) was determined by subtracting the response time to a $\mathrm{KCl}$ pulse from the one to the respective elicitor used (Fig. 1A).

\section{Measurements \\ of $\mathrm{K}^{+}, \mathrm{Ca}^{2+}$, and $\mathrm{H}^{+}$using ion-selective microelectrodes.}

Both the fabrication of ion-selective microelectrodes and their extracellular application, in particular in the root hair space, have been described previously (Felle 1993; Felle et al. 1998). Briefly, pipettes with tips of approximately $2 \mu \mathrm{m}$ were pulled on a two-stage puller (List, Darmstadt, Germany) and heat polished. Internal silanization was carried out after heating the pipettes to $200^{\circ} \mathrm{C}$ for approximately $1 \mathrm{~h}$ by dipping the rear ends into a $0.2 \%$ tributyl-silane/chloroform solution. To obtain a covalent bonding of the silane with the glass surface, the pipettes were heated for another hour. Cool pipettes were backfilled with the sensor. To give the sensor in the tip enough firmness to stay in place for extended use, the respective sensor cocktail (Fluka, Darmstadt, Germany) was dissolved in a mixture of poly(vinylchloride)/tetrahydrofuran $\left(40 \mathrm{mg} \mathrm{ml}^{-1}\right)$ at a ratio of $30 / 70(\mathrm{vol} / \mathrm{vol})$. After evaporation of the tetrahydrofuran, the remaining firm gel was topped up with the undiluted sensor cocktail, followed by the reference solution, required for the respective ion to be tested. After equilibration, these electrodes gave stable responses for at least 2 weeks, when stored in a dry chamber (silica gel). To measure ion activities and ion fluxes within the respective root hair zone, electrode tips were placed approximately $10 \mu \mathrm{m}$ from the root surface. Electrodes were connected to a high-impedance amplifier (FD 223; World Precision Instruments) which simultaneously measured and subtracted the signals obtained from the ionselective electrode and the voltage reference.

\section{Binding assays.}

Preparation of the root membrane proteins was carried out according to Cosio and associates (1988). Protein content was measured according to Bradford (1976). Binding assays were performed with 100 to $150 \mu \mathrm{g}$ of membrane protein, which was incubated with increasing concentrations of $\beta$-glucans with a different DP in the presence of $3 \mathrm{nM}{ }^{125}$ I-labeled 2-(4aminophenyl)ethylamine conjugate of hepta- $\beta$-glucoside as radioligand for $2 \mathrm{~h}$ on ice (Cosio et al. 1988). Synthesis of the radioligand was described earlier (Cosio et al. 1990). Values for half-maximal displacement $\left(\mathrm{IC}_{50}\right)$ of the radioligand were calculated from the data by nonlinear regression using Sigmaplot 7.0 (Jandel Scientific, San Rafael, CA, U.S.A.).

\section{ACKNOWLEDGMENTS}

This work was supported in part by the European Community's Human Potential Program under contract HPRN-CT-2002-00251, SACC-SIG-NET, and by the Deutsche Forschungsgemeinschaft (SFB 369, Fe 213/12-1). We thank J. Fliegmann for critical comments on the manuscript.

\section{LITERATURE CITED}

Blume, B., Nürnberger, T., Nass, N., and Scheel, D. 2000. Receptor-mediated increase in cytoplasmic free calcium required for activation of pathogen defense in parsley Plant Cell 12:1425-1440.

Boller, T. 1995. Chemoperception of microbial signals in plant cells. Annu. Rev. Plant Physiol. Plant Mol. Biol. 46:189-214.

Bradford, M. M. 1976. A rapid and sensitive method for the quantitation of microgram quantities of protein utilizing the principle of protein-dye binding. Anal. Biochem. 72:48-254.

Cheong, J.-J., and Hahn, M. G. 1991. A specific, high-affinity binding site for the hepta- $\beta$-glucoside elicitor exists in soybean membranes. Plant Cell 3:137-147.

Cosio, E. G., Feger, M., Miller, C. J., Antelo, L, and Ebel, J. 1996. High affinity binding of fungal $\beta$-glucan elicitors to cell membranes of species of the plant family Fabaceae. Planta 200:92-99.

Cosio, E. G., Frey, T., Verduyn, R., van Boom, J., and Ebel, J. 1990. Highaffinity binding of a synthetic heptaglucoside and fungal glucan phytoalexin elicitors to soybean membranes. FEBS (Fed. Eur. Biol. Soc.) Lett. 271:223-226.

Cosio, E. G., Pöpperl, H., Schmidt, W. E., and Ebel, J. 1988. High-affinity binding of fungal $\beta$-glucan fragments to soybean (Glycine max L.) microsomal fractions and protoplasts. Eur. J. Biochem. 175:309-315.

Demidchik, V., Bowen, H. C., Maathuis, F. J. M., Shabala, S. N., Tester, M. A., White, P. J., and Davies, J.M. 2002a. Arabidopsis thaliana root non-selective cation channels mediate calcium uptake and are involved in growth. Plant J. 32:799-808.

Demidchik, V., Davenport, R. J., and Tester, M. 2002b. Nonselective cation channels in plants. Annu. Rev. Plant Biol. 53:67-107.

Ebel, J. 1998. Oligoglucoside elicitor-mediated activation of plant defense. BioEssays 20:569-576.

Ebel, J., and Mithöfer, A. 1998. Early events in the elicitation of plant defense. Planta 206:335-348.

Ebel, J., and Scheel, D. 1997. Signals in host-parasite interactions. Pages 85-105 in: The Mycota V. Plant Relationships, Part A. G. C. Caroll and P. Tudzynski, eds. Springer Verlag, Berlin.

Felix, G., Baureithel, K., and Boller, T. 1998. Desensitization of the perception system for chitin fragments in tomato cells. Plant Physiol. 117:643-650

Felix, G., Regenass, M., and Boller, T. 1993. Specific perception of subnanomolar concentrations of chitin fragments by tomato cells: induction of extracellular alkalinization, changes in protein phosphorylation, and establishment of a refractory state. Plant J. 4:307-316.

Felle, H. H. 1993. Ion-selective microelectrodes-their use and importance in modern plant-cell biology. Bot. Acta 106:5-12.

Felle, H. H., Kondorosi, E., Kondorosi, A., and Schultze, M. 1995. Nod signal-induced plasma membrane potential changes in alfalfa root hairs are differentially sensitive to structural modifications of the lipochitooligosaccharide. Plant J. 7:939-947.

Felle, H. H., Kondorosi, E., Kondorosi, A., and Schultze, M. 1998. The role of ion fluxes in Nod factor signaling in Medicago sativa. Plant $\mathrm{J}$. 13:455-463.

Felle, H. H., Kondorosi, E., Kondorosi, A., and Schultze, M. 2000. How alfalfa root hairs discriminate between Nod factors and oligochitin elicitors. Plant Physiol. 124:1373-1380.

Granado, J., Felix, G., and Boller, T. 1995. Perception of fungal sterols in plants: subnanomolar concentrations of ergosterol elicit extracellular alkalinization in tomato cells. Plant Physiol. 107:486-490.

Ivashikina, N., Becker, D., Ache, P., Meyerhoff, O., Felle, H. H., and Hedrich, R. 2001. $\mathrm{K}^{+}$channel profile and electrical properties of Arabidopsis root hairs. FEBS (Fed. Eur. Biol. Soc.) Lett. 508:463-469.

Jabs, T., Tschöpe, M., Colling, C., Hahlbrock, K., and Scheel, D. 1997. Elicitor-stimulated ion fluxes and $\mathrm{O}^{2-}$ from the oxidative burst are essential components in triggering defense gene activation and phytoalexin synthesis in parsley. Proc. Natl. Acad. Sci. U.S.A. 94:48004805

Kadota, Y., Goh, T., Tomatsu, H., Tamauchi, R., Higashi, K., Muto, S., and Kuchitsu, K. 2004. Cryptogein-induced initial events in tobacco BY-2 cells: Pharmacological characterization of molecular relationship among cytosolic $\mathrm{Ca}^{2+}$ transients, anion efflux and production of reactive oxygen species. Plant Cell Physiol. 45:160-170.

Kikuyama, M., Kuchitsu, K., and Shibuya, N. 1997. Membrane depolari- 
sation induced by $\mathrm{N}$-acetylchitooligosaccharide elicitor in suspensioncultured rice cells. Plant Cell Physiol. 38:902-909.

Kuchitsu, K., Yazaki, Y., Sakano, K., and Shibuya, N. 1997. Transient cytoplasmic $\mathrm{pH}$ change and ion fluxes through the plasma membrane in suspension-cultured rice cells triggered by $N$-acetylchito-oligosaccharide elicitor. Plant Cell Physiol. 38:1012-1018.

Kurkdjian, A., Bouteau, F., Pennarun, A.-M., Convert, M., Cornel, D., Rona, J.-P., and Bousquet, U. 2000. Ion currents involved in early Nod factor response in Medicago sativa root hairs: a discontinuous singleelectrode voltage-clamp study. Plant J. 22:9-17.

Lecourieux, D., Mazars, C., Pauly, N., Ranjeva, R., and Pugin, A. 2002. Analysis and effects of cytosolic calcium increases in response to elicitors in Nicotiana plumbaginifolia cells. Plant Cell 14:2627-2641.

Mathieu, Y., Kurkdjian, A., Xia, H., Guern, J., Koller, A., Spiro, M. D., O’Neill, M., Albersheim, P., and Darvill, A. 1991. Membrane responses induced by oligogalacturonides in suspension-cultured tobacco cells. Plant J. 1:333-343.

Mithöfer, A., Ebel, J., Bhagwat, A. A., Boller, T., and Neuhaus-Url, G. 1999. Transgenic aequorin monitors cytosolic calcium transients in soybean cells challenged with $\beta$-glucan or chitin elicitors. Planta 207:566-574.

Mithöfer, A., Fliegmann, J., Daxberger, A., Ebel, C., Neuhaus-Url, G., Bhagwat, A. A., Keister, D. L., and Ebel, J. 2001. Induction of $\mathrm{H}_{2} \mathrm{O}_{2}$ synthesis by $\beta$-glucan elicitors in soybean is independent on cytosolic calcium transients. FEBS (Fed. Eur. Biol. Soc.) Lett. 509:191-195.

Mithöfer, A., Fliegmann, J., Neuhaus-Url, G., Schwarz, H., and Ebel, J. 2000. The hepta- $\beta$-glucoside elicitor-binding proteins from legumes represent a putative receptor family. Biol. Chem. 381:705-713.

Newman, I. A. 2001. Ion transport in roots: measurement of fluxes using ion-selective microelectrodes to characterize transporter function. Plant Cell Environ. 24:1-14.

Nürnberger, T., Nennstiel, D., Jabs, T., Sacks, W. R., Hahlbrock, K., and Scheel, D. 1994. High affinity binding of a fungal oligopeptide to parsley plasma membranes triggers multiple defense responses. Cell 78:449-460.

Nürnberger T., and Scheel, D. 2001. Signal transmission in the plant immune response. Trends Plant Sci. 6:372-379.

Pelessier, B., Thibaud, J.-B., Grignon, C., and Esquerré-Tugayé M.-T.
1986. Cell surface in plant-microorganism interaction. Elicitor preparations from two fungal pathogens depolarize plant membrane. Plant Sci. 46:103-109.

Pike, S. M., Adam, A. L., Pu, X.-A., Hoyos, M. E., Laby, R., Beer, S. V., and Novacky, A. 1998. Effects of Erwinia amylovora harpin on tobacco leaf cell membranes are related to leaf necrosis and electrolyte leakage and distinct from perturbations caused by inoculated E. amylovora. Physiol. Mol. Plant Pathol. 53:39-60.

Pugin, A., Frachisse, J.-M., Tavernier, E., Bligny, R., Gout, E., Douce, R., and Guern, J. 1997. Early events induced by the elicitor cryptogein in tobacco cells: involvement of a plasma membrane NADPH oxidase and activation of glycolysis and the pentose phosphate pathway. Plant Cell 9:2077-2091.

Schmidt, W. E., and Ebel, J. 1987. Specific binding of a fungal glucan phytoalexin elicitor to membrane fractions from soybean Glycine max. Proc. Natl. Acad. Sci. U.S.A. 84:4117-4121.

Shibuya, N., and Minami E. 2001. Oligosaccharide signaling for defence responses in plants. Physiol. Mol. Plant Pathol. 59:223-233.

Thain, J. F., Gubb, I. R., and Wildon, D. C. 1995. Depolarisation of tomato leaf cells by oligogalacturonide elicitors. Plant Cell Environ. 18:211214.

Wendehenne, D., Lamotte, O., Frachisse, J.-M., Barbier-Brygoo, H., and Pugin, A. 2002. Nitrate efflux is an essential component of the cryptogein signaling pathway leading to defense responses and hypersensitive cell death in tobacco. Plant Cell 14:1937-1951.

White, P. J., and Davenport, R. J. 2002. The voltage-independent cation channel in the plasma membrane of wheat roots is permeable to divalent cations and may be involved in cytosolic $\mathrm{Ca}^{2+}$ homeostasis. Plant Physiol. 130:1386-1395.

Zimmermann, S., Nürnberger, T., Frachisse, J.-M., Wirtz, W., Guern, J. Hedrich, R., and Scheel, D. 1997. Receptor-mediated activation of a plant $\mathrm{Ca}^{2+}$-permeable ion channel involved in pathogen defense. Proc. Natl. Acad. Sci. U.S.A. 94:2751-2755.

Zimmermann, S., Frachisse, J.-M., Thomine, S., Barbier-Brygoo, H., and Guern, J. 1998. Elicitor-induced chloride efflux and anion channels in tobacco cell suspensions. Plant Physiol. Biochem. 36:665-674. 